\title{
A REWARDING PURSUIT
}

\section{Hugh McLaughlin, Lewvan}

$\mathbf{P}$ RAPS the man who had picked a rooster off its perch, deftly bled and plucked it, and in complacent ease could conjure up a roast fowl, would be a bit pained if you asked him to arise early in the morningbefore dawn and go wading in some marsh-on the possible chance of bringing home some wild game. He would not know that your shivering in the chill dawn was not from cold alone, but partly an appreciation of the hunt-a tingle not unlike that of your eager bird dog.

Another state similar to this might be the early rising hunter who could not view without some dismay the "hunter" who departeri for the marshes without a gun but rather with an open ear and eye-field glasses or camera-a different approach of the same quarry-but the call of the wild just as impelling. True, the red morning sky as it emerges from the grayness overlying the horizon-the reeds that appear from the shadows in the waters- the soft sounds of awakening lifeliquid tones of a bittern-a curious marsh wren whose quarters you have invaded-a $\mathrm{V}$ in the water as the surface is pushed aside by a muskrat-all these sounds and sights are for both hunters.

This similarity ends suddenly with the first blast of a hunter's gunan amazing roar of wings fills the air - circling - wheeling - whistling targets-and all else is forgotten. Quite a few people are attracted to hunting before any more profound thoughts of nature's creatures enter their minds, but it is a step forward to be able to perceive that all game is not brought home in a bag. That to live quietly beside this wildlifeto pry into their secret lives and to contemplate their sounds-to come home with a picture in the mind only of some aspect of the lives of the marsh is also a rewarding pursuit. Long after the bones are picked from a bird, the morning sky over the marsh and the whistling wings remain fixed in our memory.

\section{Across Western Canada with the Birds in December}

\section{Clarissa Stewart, Fairy Hill}

"One for sorrow, two for joy, Three for a girl and fou' for a boy. ..... Seven for a secret."

7 HE only rhyme came to mind as we commenced our long drive from central Saskatchewan to interior British Columbia. A Magpie soared across our path: "One for sorrow," said I, and a second appearing-"two for joy." Then I ceased to count, for they flew, with their lustrous ebony heads and shining snow-white cowls, at frequent intervals, from the Qu'Appelle Valley to the Okanagan Valley; south of the border between the State of Washington to the Province of British Columbia. One wonders what these predators feed upon when the songbirds have migrated, leaving empty nests.

On the Regina plains a small flock of blackbirds were observed and companies of Barn Pigeons gleaned from the wheat left by grain trucks on the highways. Then Snow-bunt- ings in large gatherings began to fly before the wind, veering with each gust. These appeared all across Dakota and Montana in the wintry landscape. A Downy Woodpecker was seen on the trunk of a tree in a smalltown. On a snowy windswept plain, east of the Grand Coulee Dam in Washington, a bedraggled Meadowlark staggered uncertainly by the side of the road. Poor thing! It couldn't long survive the snow and raw damp weather, and we were driving too fast to try and rescue it.

Coming westward on the Kamloops road, a solitary belated Robin flitted from tree to tree in the mild Okanagan air. A flock of Blackbirds, not yet gone to winter quarters, crossed the road and settled on a rail fence. And near the barns of a small farmstead a tree appeared to be laden with some sort of plump fruit, which on closer view, proved (Continued on page 7 ) 


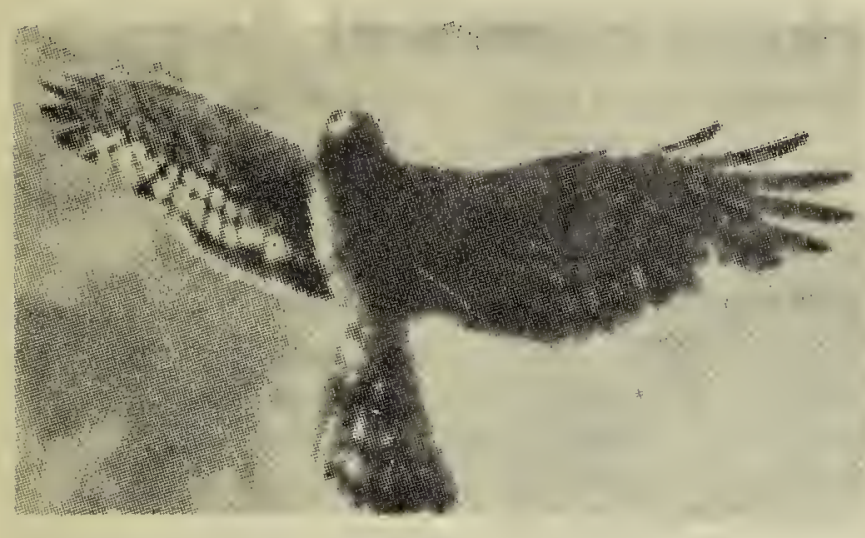

The true chicken hawks, the bluebacked, round-winged, long-tailed accipters such as the Cooper's and Sharp-shinned cause us little worry. We only see them in migration when we have no small chickens on the loose. They are hated by all smail birds and when one does turn up kingbirds, sparrows, blackbirds ali join in chasing them off. A few years ago we saw these birds during the summer and believed a few nested here. Now with a lot more of the land cleared we no longer see them except in migration.

The two Rough-legged hawks, and the larger falcons we see only in migration, and the Goshawk as a rare winter visitor.

Both the Bald and Golden eagle pay us sporadic visits, sometimes of but a few moments duration, at other times hanging around less habited parts of the district for weeks. Young of both the Bald and Golden eagles have come right into our yard at different times. A few years ago a young Golden eagle picked up a pullet but dropped ii when the men who were only a few yards away shouted. However, this boldness seems to go with youth and I've never seen an adult so close.

\section{Across Western Canada with the Birds in December}

\section{(Continued from page 5)}

to be Grosbeaks, doubtless from northern regions colder than they liked.

Where we came to rest in the northern part of the Okanagan Valley, a bright colored pheasant awakened us each dawn with his hoarse crowing and could be seen of a morning walking proudly through the pines and past the house, even in the city, built as it is, on hills and in hollows.

\section{BIRD SONG RECORDS}

\section{Harold Kreinge, Hawarden}

I wonder if our readers know about the Vinylite bird-song records sold by the T. A. Allen Company of Toronto. Volume 1 records 72 calls and songs of American birds, and Volume 2 records 50 calls of songs of birds. Many of the recordings are realistic and wonderfully natural. I have both of these volumes as well as a third which records the calls of 24 Eastern North American frogs and toads. It is splendid.

\section{A BOLT FROM THE BLUE}

\section{By Arthur Ward, Swift Current}

It was approaching dusk, and standing in front of one of the traps in order to let a banded bird free, there came a resounding thud against the back of the trap. Momentarily I was so taken aback that the hawk recovered and flew away. It had seen the bird (Harris Sparrow) in the trap and apparently had struck the trap feet first. Had it been head first it would have knocked itself out. It all happened so quickly that I could not identify it, but it looked like a Cooper's Hawk.

"I enjoy every article, and would not like to miss a single copy. I find Arch Budd's floral offerings most interesting, and love to walk with Elizabeth Cruickshank on her little tours and trips to the Valley."

-Mrs. Arthur Thompson, Rangor.

\section{APPRECIATION}

"I get an opportunity to see quite a few Society magazines but I believe the BLUE JAY is the most alive of any. Folks from the utmost places in the province have a finger in itand what a change from that mimeographed sheet!"

-P. H. Du Boulay, Montreal. 